\title{
Secondary School Students' English Literacy: Use of Interactive Read Aloud Instructional Strategy
}

Mutiara Ayu, Chuzaimah Dahlan Diem*, Machdalena Vianty

Sriwijaya University, Palembang, Indonesia

Corresponding Author: Chuzaimah Dahlan Diem, E-mail: chuzaidd@gmail.com

\section{ARTICLE INFO}

\section{Article history}

Received: June 07, 2017

Accepted: August 19, 2017

Published: December 01, 2017

Volume: 6 Issue: 7

Special Issue on Language \& Literature Advance access: September 2017

Conflicts of interest: None Funding: None

\begin{abstract}
The Global era has had a great impact on the existence of English as a global language which requires students to be good at its every skill. It is believed that students' English could be enhanced well with the use of certain strategies, one of which is Interactive Read Aloud Instructional Strategy (IRAIS). This study was aimed at examining the efficacy of IRAIS to help students to improve their English literacy achievements. Forty five out of 746 students were selected randomly as sample based on their grade levels $\left(7^{\text {th }}, 8^{\text {th }}, 9^{\text {th }}\right)$ and their levels of comprehension. By using time series design, these students were given interventions for three months using IRAIS and their English achievements were obtained from pre- and post-tests of four English literacy skills. During the interventions, the progress of the students was also monitored regularly by using three formative tests. The results showed consistent progress on the students' achievement during the interventions and upon their total English literacy achievement after the interventions. Among the four English literacy skills, the most significant improvement was in listening followed by writing, reading, and speaking. In terms of aspects of each literacy skill, the highest achievement scores were in inference of listening, narrative techniques of writing, vocabulary of reading, and vocal expression of speaking. These findings lead to the conclusion that IRAIS is an effective strategy in helping students to improve their level of English proficiency.
\end{abstract}

Key words: English Literacy, Interactive Read Aloud, Instructional Strategy, Secondary Students

\section{INTRODUCTION}

The growth of the use of English as international communication has apparently been continuing in this $21^{\text {st }}$ century. English has been used as the language of science, technology, academia, youth culture, mass media, and business among people from different nations, languages, or cultures on various occasions requiring them to be good at its every skill (Crystal, 2003; Graddol, 2006). Moreover, this issue also happens to Indonesian people who are encountering the cooperation with other Southeast Asian countries through Asean Economic Community. In this context, having English literacy skills is important for everyone living in this globalization era including adolescent to compete with others who use English as a means of communication.

In Indonesia, English has a special place in the school curriculum since it starts to be taught in junior high school as a compulsory subject in order to make students ready to face competitiveness in the $21^{\text {st }}$ century. It is taught to develop students' potency in order to have a communicative competence in the interpersonal, transactional, and functional discourses using the kind of texts in oral and written English language (Ministry of Education and Culture, No. 58, 2014).
In addition, English will eventually be very useful for them to participate and compete in global society which is emphasized in Goal 4.6 of Quality Education in the 17 Global Goals "By 2030, ensure that all youth and a substantial proportion of adults, both men and women, achieve literacy and numeracy" (United Nation, 2015, p. 41).

Unfortunately, the reality does not happen like that. Literacy is still a problem in Indonesia. UNESCO Institute for Statistics (2015) has proven the total number of illiterate people in national literacy populations in Indonesia among those aged $15-24$ years old is 441,$045 ; 249,686$ males and 191,360 females. The result of the CIA World Factbook (2014) also showed that literacy level in Indonesia is ranked $121^{\text {st }}$ out of 215 countries around the world. PIRLS (2012) also showed that Indonesian students' reading literacy was not any better and put Indonesia in the $42^{\text {nd }}$ rank of 45 countries with the average score of only 428 while the PIRLS scale counterpoint was 500 (IEA, 2012).

Moreover, according to the 2015 Education First English Proficiency Index, Indonesia ranks fourth in the Southeast Asian region, down one position from last year, as Vietnam managed to outpace Indonesia in terms of English proficiency level growth. Indonesia's score on the worldwide ranking was 52.91 placing it in the $32^{\text {nd }}$ position out of 70 countries 
(EF-EPI, 2015, p.31). With the growth of Indonesian's English proficiency level progressing very slowly, Indonesian people may face problems to compete with other people in ASEAN as the region prepares itself for the ASEAN Economic Community.

In local context, an investigation done by Diem, Vianty, and Mirizon in 2016 reveal that the score of English comprehension achievement of 355 junior high school students of different state public schools in Palembang is 65, while the Minimum Competency Criteria (Kriteria Ketuntasan Minimum) is 75 . This condition has been very discouraging because English has been a compulsory subject since it is first introduced to junior high school in Indonesia to anticipate the needs of communication in the global era. This fact requires teachers to work harder to solve the problem so that the same condition will not happen to future generation.

Since English is not an easy language to master, the teaching of English should be conducted with certain teaching strategies in order to help the students to improve their achievement. According to Boundless Education (2016), effective teaching strategies help to activate students' curiosity about a class topic, engage students in learning, develop critical thinking skill, keep students on task, and maintain classroom interaction. It means the strategy used by the teacher facilitates learning, motivates learners, engages them in learning, and helps them focus. In short, teaching strategies may influence and enhance the results of learning and determine the success or failure of the process of teaching and learning activities. This assumption is in line with the result of the study done by Harmon (2002) which shows that students' comprehension is influenced by the strategies used by the teacher.

As previously described, the use of a teaching strategy can potentially make a difference. In this study, the strategy that is proposed to improve English literacy of the students is Interactive Read Aloud Instructional Strategy (IRAIS). According to some scholars, such as Lane and Wright (2007), the interactive read aloud is based on three essential understandings, encouraging the child to become an active listener during book reading, providing feedback that models more sophisticated language, and challenging the child's knowledge and skills by raising the complexity of the conversation to a level just above the child's current ability. In the interactive strategy, particularly the quality of the teachers' language that they share with their students and the books they read aloud, are strongly related to their students' language development. IRAIS places more responsibility on students to share what they are thinking in a way that simulates an authentic reading experience than do traditional read aloud practices (O'Flahavan, 2007). Barrentine (1996, p. 36) states that interactive read aloud encourages children to verbally interact with the text, peers, and teacher. This approach to reading aloud provides a means of engaging students as they construct meaning and explore the reading process.

Considering the benefits of IRAIS, this study primarily focused on helping secondary school students to improve their English literacy achievements from their young-adult age by using IRAIS for a better quality education as the foundation of sustainable development in this century.

\section{LITERATURE REVIEW}

Interactive read aloud instructional strategy has become an instructional method to incorporate in the classroom because they offer the same and additional benefits as read aloud. The term "interactive read aloud" was first used in the early 1990's. Interactive read aloud became more prevalent when S.J. Barrentine, wrote articles for the International Reading Association's, The Reading Teacher, about how to use them in the classroom.

Barrentine's (1996) defines interactive read aloud as follows, "... a teacher poses questions throughout the reading that enhance meaning construction and also show how one makes sense of text" (p. 36). During the process, Barrentine suggests the teacher stops and asks questions to engage students in conversations about the text. These conversations help the students become aware of elements in the story that they might not otherwise notice. They are also able to hear their peers' ideas and perspectives.

According to Wiseman (2011), interactive read aloud affords opportunities for making meaning through conversations and student interactions, which provides students with the opportunities to interact with the text and build their knowledge and strengths. Additionally, Wiseman suggests interactive read aloud provides opportunities that are more than skill and literacy development; they are a time for teachers and students to create, extend and recognize certain examples of knowledge. As a result, interactive read aloud allows students to become actively involved in their learning and give purpose to the learning process.

Many researchers have demonstrated that read aloud is an effective way to introduce students to the joys of reading. For instance, McGee and Schickedanz (2007) explain that during an interactive read aloud, teachers talk as they read to model their own thinking. This modeling helps the students understand and notice what the teacher is predicting, inferring, connecting, and processing in the story. This process helps the students interpret and understand the text by sharing ideas that likely would not be natural for the reader.

Interactive read aloud clearly has many benefits when teachers and students interact and discuss texts. As students listen to stories being read aloud, they gain new words, begin to figure out how letters and sounds are related (phonological awareness), and learn how words are conceptually related (Biemiller \& Boote, 2006). It means the more words students know, the more they are involved and engaged with the stories, and the more likely they become successful readers. Ultimately, the enhanced vocabulary that students acquire through an interactive read aloud aids their ability to be independent readers and learners. Furthermore, students who are stimulated, routinely read, engaged and asked about books will thrive and be successful in school. Providing students strong literacy education in the early years leads to better outcomes later on.

\section{METHOD}

This study was conducted through an experiment to know the efficacy of interactive read aloud instructional strategy 
(IRAIS) on English literacy achievement. Since the focus was on English literacy both as a whole and partial improvement, it required three months to do the intervention and observation to see students' regular progress in learning. Therefore, equivalent time series design was chosen, in which a pretest, an intervention, and a posttest were purposively given. "The essence of the time-series design is the presence of a periodic measurement process on some group or individual and the introduction of an experimental change into this time series of measurements, the results of which are indicated by a discontinuity in the measurements recorded in the time series" (Campbell \& Stanley, 1963, p. 37). Meanwhile, the progress of the students was regularly monitored during the intervention by using some observations called formative evaluations or tests. The intervention by using IRAIS was given six periods of successive four meetings in each period. Each meeting focused on two skills and after one period the students were given a formative test to check their progress.

\section{Participants}

The sample of this study is 45 students consisting of seventh, eighth and ninth graders of a state junior high school from City Based District in Palembang in the academic year 2016/2017. They were randomly selected out of 90 students based on students' gender, grades, and levels of comprehension achievement, namely, below average, average and above average. This selection of the sample was based on the result of the survey study done by Diem, Vianty, and Mirizon (2016) which shows that both grades and locations make a difference in students' levels of comprehension achievement of 355 students which is also still low $($ mean $=65)$.

\section{Instruments}

To collect the data, preliminary tests and English literacy tests were given to the sample in this study. The Informal Reading Inventory developed by Stark (1981) was given to the sample prior to the English literacy tests and the experiment to assess the students' instructional reading level. Then, the students were given English literacy tests consisting of listening, reading, writing, and speaking tests before, during and after the interventions. The listening and reading tests were given to the students with the same passages using 32 questions for each test in the form of multiple choice questions which consisted of six aspects, such as main idea, detail, sequence, inference, cause and effect, and vocabulary. For the writing test, the students were asked to write a short story which consisted of generic structure of narrative text, namely, orientation, complication and resolution in 40 minutes and for the speaking test, they had to tell what they had written in the writing test for 5-7 minutes. Students' writing skill achievement was scored using CCSS Narrative Writing Rubric developed by the Elk Grove Unified School (2012) and their speaking skill achievement was scored by using NET Working Storytelling Rubric (Networking Stuard Mead \& Adrian Tilley, 2012) by two raters who are lecturers of English and their TOEFL score is above 570.

\section{RESULTS AND DISCUSSION}

The data gathered from students' tests are presented using descriptive statistics and statistical analyses. The results of the students' English literacy achievement ${ }_{\text {Total }}$, each literacy skill, and aspects of every skill were analyzed using paired sample t-test to find out students' improvement after they were taught by using IRAIS. Then, the stepwise regression analysis was used to obtain the information about the statistical contribution of each literacy skill (Listening, Reading, Writing, and Speaking) to English literacy achivement $\left(\mathrm{ELA}_{\text {Total }}\right)$ and each aspect of each skill to every skill Total $_{\text {. }}$.

\section{Descriptive Statistics}

The data gathered from pre- and post-tests given to the students are presented in this part. The students' scores, which have been categorized into three levels, show that in the pre-test, $80 \%$ of the students was still below average level and $20 \%$ was average level. As a whole, the students' literacy achievement was below average with the mean score of 55.69. After the intervention, the students' achievement improved significantly with the mean score of $73.38 .28 .9 \%$ of the students was above average level, $71.1 \%$ was average level and none were below average level.

Many students achieved satisfactory results after they were given treatments, there was a significant difference between pre- and post-test scores. Among the four skills reading skill has the highest mean score of 81.40 . There were $33(73.3 \%)$ students above average level and only $12(26.7 \%)$ students reached average level. For listening, most of students achieved satisfactory results, 17 students (37.8\%) were on the above average level and 28 (62.2\%) students were on the average level.

For writing, the mean score of the-post test was 71.15; $14(31.1 \%)$ students were above average, 25 (55.6\%) students were average level and $6(13.3 \%)$ students were below average. For speaking, the post-test results showed that most of the students' speaking level was on the average, it was shown by the results that $29(64.4 \%)$ students were on the average level, $10(23.3 \%)$ students were on below average level and only 6 (13.3\%) students were above averagelevel.

\section{Statistical Analysis of Paired Sample T-test}

The results of English literacy achievement, $\left(\mathrm{ELA}_{\text {Total }}\right)$, each literacy skill, and its aspects were analysed using paired sample t-test to find out whether or not there was a significant difference between pre-test and post-test in order to see significant improvement in students' ELA $_{\text {Total }}$ after they were given treatment.

Table 2 reveals that the mean difference between pretest and post-test of ELA ${ }_{\text {Total }}$ was 19.45, the $\mathrm{t}$ - obtained was 43.190 and the level of significance was .000 which means there was a significant improvement in students' English literacy achievement ${ }_{\text {total }}$ after they were taught by using IRAIS. 


\section{Statistical Analysis of Formative Tests}

In addition to pre and post test, there were 3 formative tests of each skill given to the students during the teaching and learning process in order to see students' progress.

The first formative test (F1) showed that reading and speaking skills had the highest score with $\mathrm{t}_{\text {-obtained }} 12.46$ and 11.50 respectively. Then, the students performed significant progress on their listening most followed by reading, speaking, and writing consecutively in the second formative test (F2). Finally, at the last formative test, the students showed their best progress in which their most significant progress were in writing and speaking skills with $\mathrm{t}_{\text {-obtained }}=12.24$ and $=15.65$ respectively. See Table 3.

Table 1. Score distribution of students' English literacy achievement ${ }_{\text {Total }}$ and each of its skills based on achievement categories $(\mathrm{N}=45)$

\begin{tabular}{|c|c|c|c|c|c|c|c|c|c|c|}
\hline \multirow[t]{2}{*}{ Variables } & \multirow{2}{*}{$\begin{array}{c}\text { Score } \\
\text { interval }\end{array}$} & \multirow{2}{*}{$\begin{array}{l}\text { Achievement } \\
\text { category level }\end{array}$} & \multicolumn{4}{|c|}{ Pre-test } & \multicolumn{4}{|c|}{ Post-test } \\
\hline & & & $\mathbf{N}$ & $\%$ & Mean & Standard & $\mathbf{N}$ & $\%$ & Mean & Standard \\
\hline \multirow[t]{3}{*}{ ELA $_{\text {Total }}$} & $76-100$ & Above average & - & - & & & 13 & 28.9 & & \\
\hline & $61-75$ & Average & 9 & 20 & 55.69 & 6.605 & 32 & 71.1 & 73.38 & 5.861 \\
\hline & $0-60$ & Below average & 36 & 80 & & & - & - & & \\
\hline \multirow[t]{3}{*}{ Reading } & $76-100$ & Above average & 10 & 22.2 & & & 33 & 73.3 & & \\
\hline & $61-75$ & Average & 21 & 46.7 & 65.49 & 10.242 & 12 & 26.7 & 81.40 & 8.378 \\
\hline & $0-60$ & Below average & 14 & 31.1 & & & - & - & & \\
\hline \multirow[t]{3}{*}{ Listening } & $76-100$ & Above average & - & - & & & 17 & 37.8 & & \\
\hline & $61-75$ & Average & 10 & 22.2 & 54.59 & 6.609 & 28 & 62.2 & 75.35 & 6.636 \\
\hline & $0-60$ & Below average & 35 & 77.8 & & & - & - & & \\
\hline \multirow[t]{3}{*}{ Writing } & $76-100$ & Above average & 2 & 4.4 & & & 14 & 31.1 & & \\
\hline & $61-75$ & Average & 9 & 20 & 52.81 & 11.209 & 25 & 55.6 & 71.15 & 8.719 \\
\hline & $0-60$ & Below average & 34 & 75.6 & & & 6 & 13.3 & & \\
\hline \multirow[t]{3}{*}{ Speaking } & $76-100$ & Above average & - & - & & & 6 & 13.3 & & \\
\hline & $61-75$ & Average & 5 & 11.1 & 49.92 & 7.157 & 29 & 64.4 & 65.63 & 7.991 \\
\hline & $0-60$ & Below average & 40 & 88.9 & & & 10 & 22.3 & & \\
\hline
\end{tabular}

Table 2. Results of paired samples t-test of English literacy achievement

\begin{tabular}{lcccccc}
\hline Variables & \multicolumn{2}{c}{ Mean score } & & Mean difference pre and post test & t-value & Sig (2-tailed) \\
\cline { 2 - 4 } & Pre-test & Post-test & & & \\
\hline ELA Total & 61.72 & 81.17 & 19.45 & 43.190 & 0.000 \\
Listening & 17.45 & 24.11 & 6.66 & 43.446 & 0.000 \\
Reading & 20.96 & 26.04 & 5.08 & 25.061 & 0.000 \\
Writing & 13.27 & 17.84 & 4.57 & 15.764 & 0.000 \\
Speaking & 10.04 & 13.18 & 3.14 & 24.961 & 0.000 \\
\hline
\end{tabular}

Table 3. Results of paired samples T-test of formative tests of the four English skills

\begin{tabular}{|c|c|c|c|c|c|c|c|c|c|c|c|c|c|}
\hline \multirow[t]{2}{*}{ Variables } & \multicolumn{5}{|c|}{ Mean score } & \multicolumn{4}{|c|}{ Mean difference } & \multicolumn{4}{|c|}{ t-value and Sig. (2-tailed) } \\
\hline & Pre & F1 & F2 & F3 & Post & Pre-F1 & F1-F2 & F2-F3 & F3-Post & Pre-F1 & F1-F2 & F2-F3 & F3-Post \\
\hline ELA & 61.72 & 64.84 & 69.90 & 74.63 & 81.17 & 3.12 & 5.06 & 4.73 & 6.55 & $\begin{array}{l}26.45 \\
0.000\end{array}$ & $\begin{array}{l}22.97 \\
0.000\end{array}$ & $\begin{array}{l}23.51 \\
0.000\end{array}$ & $\begin{array}{l}26.00 \\
0.000\end{array}$ \\
\hline Reading & 20.96 & 22.00 & 23.29 & 24.42 & 26.04 & 1.04 & 1.29 & 1.13 & 1.62 & $\begin{array}{l}12.46 \\
0.000\end{array}$ & $\begin{array}{l}11.41 \\
0.000\end{array}$ & $\begin{array}{l}10.47 \\
0.000\end{array}$ & $\begin{array}{l}16.74 \\
0.000\end{array}$ \\
\hline Listening & 17.45 & 18.27 & 19.93 & 21.49 & 24.11 & 0.82 & 1.66 & 1.56 & 2.64 & $\begin{array}{c}9.79 \\
0.000\end{array}$ & $\begin{array}{l}15.81 \\
0.000\end{array}$ & $\begin{array}{l}10.63 \\
0.000\end{array}$ & $\begin{array}{l}17.29 \\
0.000\end{array}$ \\
\hline Writing & 13.27 & 13.85 & 15.18 & 16.48 & 17.84 & 0.58 & 1.33 & 1.30 & 1.36 & $\begin{array}{c}7.45 \\
0.000\end{array}$ & $\begin{array}{l}10.34 \\
0.000\end{array}$ & $\begin{array}{l}12.24 \\
0.000\end{array}$ & $\begin{array}{l}11.30 \\
0.000\end{array}$ \\
\hline Speaking & 10.04 & 10.72 & 11.50 & 12.24 & 13.18 & 0.68 & 0.78 & 0.74 & 0.93 & $\begin{array}{l}11.50 \\
0.000\end{array}$ & $\begin{array}{l}13.60 \\
0.000\end{array}$ & $\begin{array}{l}15.65 \\
0.000\end{array}$ & $\begin{array}{l}14.32 \\
0.000\end{array}$ \\
\hline
\end{tabular}


Table 4. Results of stepwise regression analyses of English literacy achievements $(\mathrm{N}=45)$. Based on each literacy skill

\begin{tabular}{lccc} 
Sub-variables of ELA model & R square & R square changed & Sig. F change \\
\hline Reading & 0.703 & 0.703 & 0.000 \\
Reading + Writing & 0.875 & 0.174 & 0.000 \\
Reading + Writing + Speaking & 0.942 & 0.068 & 0.000 \\
Reading + Writing + Speaking + Listening & 0.996 & 0.055 & 0.000 \\
\hline
\end{tabular}

\section{Results of Regression Analysis}

The stepwise regression analysis was used to obtain the information about the contribution of each literacy skill to English literacy achievement ${ }_{\text {Total }}$. The results showed that among the four skills of literacy, reading $(70.3 \%)$ had the highest contribution towards students' ELA ${ }_{\text {Total }}$. The other contributions were from writing $(17.4 \%)$, speaking $(6.8 \%)$, and listening $(5.5 \%)$.

Furthermore, each aspect of each skill was also analyzed to see its contribution towards each literacy skill (total) by using stepwise regression analyses. For students' reading skill the results showed only inference contributed the highest $(56.8 \%)$. The rest was contributed by main idea $(17.6 \%)$, details $(13.3 \%)$, cause and effect $(5.6 \%)$, sequence $(3.4 \%)$ and vocabulary $(3.2 \%)$.

For the students' writing skill achievement ${ }_{\text {Total }}$, organization aspect gave the highest contribution to writing skill achievement total in which the contribution was $82.4 \%$. Narrative techniques only contributed $10.8 \%$ followed by language and convention $3.8 \%$ and exposition gave the least contribution of all (3\%).

In speaking skill, the aspect of familiarity with the story $(81.9 \%)$ made the highest contribution towards students' speaking skill achievement ${ }_{\text {Total }}$. The other contributions were from pronunciation and fluency $(10.6 \%)$, body language $(4.9 \%)$, vocal expression $(1.5 \%)$, and vocabulary and gram$\operatorname{mar}(1 \%)$.

Finally, the results showed that six aspects of listening skill gave significant contribution towards students' listening skill achievement ${ }_{\text {Total }}$. One of the aspects of listening skill that gave the highest contribution was inference $(57.8 \%)$. Next, main idea contributed $13.6 \%$, and detail $10 \%$. However, the contribution given by cause and effect $(6.6 \%)$, vocabulary $(6.2 \%)$, and sequence $(5.8 \%)$ although less than 10 percent was also significant.

\section{DISCUSSION}

The findings of this present study have shown the effectiveness of IRAIS which eventually has improved the students' English literacy achievement in general and or its four skills in particular. It is probably due to the students' effort to connect every relevant activity with their personal lives. The effectiveness of this strategy is in line with the previous studies done by Hoffman (2011, p.183) which show that IRAIS not only is highly engaging the students in learning the language, but also promoting their language experiences and literacy development through interaction among students and teachers. In this present study, this is proven that among the four English literacy skills, the students were engaged in receptive and productive skills. It is then assumed that IRAIS has put the priority on students' active listening during book reading in which the students were encouraged to listen attentively to what was read-aloud to them without having the text with them and then followed by making comments and or asking questions later on in the discussion.

Furthermore, listening to the story read aloud well is important for developing students' listening skills. It helps the students to foster their internal listening skills and sharpen their ability comprehend the story. Delacruz (2013) and Fountas and Pinnell (2006) agree that an interactive read aloud helps to develop students' ability to listen and promote language development. They Reading aloud to students builds the foundation of literacy learning.

In addition, we believe that by having students listen before reading, the students would know more stories and have more opportunities to hear rich language with new vocabulary (Read also Fisher \& Medvic, 2003). We also believe that by giving comments and demonstrating analytic thinking in which students would make inferences about character's thoughts and feelings or predicting upcoming events in the story using such phrases as "I think," "I guess," or "I predict," the students will become accustomed to thinking critically. Giving comments focusing on getting students to infer the main character's thoughts and feeling or to connect main events with their causes after reading the entire book would help them expand their inferences and comprehension. McGee and Schickedanz (2007) also found that during interactive read aloud, teachers talk as they read to model their own thinking helps the students understand and notice what is being predicted, inferred, connected, and processed what is going on in the story. This also convinces the findings of this present study that what has made the students good at listening skill is their inference which means that they are able to interpret and synthesize their understanding about the text well. It is also proven that the main difference between students' pretest and posttest is their highest improvement on inference among the other aspects of listening skill.

In addition to their listening skill progress, the students also showed their improvement significantly in vocabulary aspect. This probably happens because as they listen, they gain new words and learn how words are related in the story. It is assumed when the story was read aloud to them, their comprehension was monitored, and discussion was done during reading aloud session, the students were encouraged to relate unfamiliar words into the story or book discussions and to guess its meaning. Therefore, it is believed 
that through this interactive activities, students must have learned new words. This confirms the finding of Hargrave and Sénéchal's study (2000) that interactive read aloud has resulted in vocabulary gains even when those interactive interventions are short. It means the more the students are involved and engaged with the stories, the more words they know, and the more likely they become successful language learners.

However, in this study, although the students made the highest improvement in listening, the results of stepwise regression results showed that reading gave the highest contribution to the students' English literacy achievement. Moreover, the post test results also showed the highest mean score among the other skills, i.e. 81.40. This means IRAIS significantly improved the students' reading comprehension achievement as well. There might be some reasons that need to be discussed regarding to the students' improvement in reading comprehension achievement.

First of all, interactive read aloud strategy is viewed as one of the oldest teaching strategy (Trerealese, 2011). This practical strategy is important to be taught to kids through the high school years (Koralek, 2003) because it can help the students to increase their understanding of the content, engage and enhance their language learning which lead the students to create meaningful connections between learning and their lives (Albright, 2002; Albright \& Ariail, 2005).

Second, it is speculated that the students' reading comprehension improvement in this present study is influenced by a meaningful discussion during the pause times in interactive process in which some questions designed in the text urge students to talk, develop the follow-up questions, connect ideas critically, and build the meaning from those ideas which are in line with the previous studies. Ediger (2002) and Shed and Duke (2008) state that the most important values learned from the discussion of the story are not only learning about the texts but also moral lessons generated in the texts.

Finally, the significant result of this study is also assumed to happen because of the implementation of setting the tone and expression in reading the story aloud. By changing the tone of voice and putting certain expressions and emphasis during the process of learning, the texts were made alive and eventually the students understood the characters quite well. The findings are also in line with some previous studies done by Nishida (2007) and Al-Manshour and Al-Shorman (2011) which found the effectiveness of interactive read aloud strategy on students' comprehension.

Concerning the improvement of students' writing which is also significant after the students' being taught with interactive read aloud activities for three months has indicated that the students must have put a big effort to write using their own words about everything they listened, read, and discussed in order to develop experiences, events, and characters which made the stories alive. Moreover, they were exposed to a variety of stories using various narrative techniques. As a result, various exposures to writing styles and structures helped them discover which writing styles they like (Read also Oueini, Bahous, \& Nabhani, 2008). This could possibly become the reason why the students perform much better in one of the writing aspects which is narrative technique.

In contrast, the students performed the lowest in exposition which is assumed that they did not really put concern to introduce a narrator and characters in the story. Some students also did not engage and orient the reader by setting out a problem and situation in their composition in the posttest. Regardless of negligible improvements in this aspect, based on stepwise regression results, organization aspect highly contributes to the writing achievement as a whole. It is probably due to that the organization is one of the noteworthy parts of a story in which a clear event is organized by the students sequentially that unfolded logically and naturally using a variety of techniques to sequence events. According to Oshima and Hogue (2007), events must be built on one another to create a coherent whole, and provide a clear conclusion. This also indicates that the students had implemented the exposures to develop the stories, starting from introducing the characters and settings to presenting the conflict and providing resolution to create a meaningful story.

The output of the statistical analysis of speaking skill shows that interactive read aloud activities have provided more opportunities for the students to have discussion and talk with peers about the stories during the learning process. In a traditional way, read aloud practices in most classrooms according to O'Flahavan (2007) involve teachers choosing a story, reading it aloud to their students, stopping occasionally to reflect on while students sit passively listening. Meanwhile, in the interactive read aloud strategy used in this present study, all students were given a chance to share their ideas and engage in conversations about what they thought. Thus, when interactions occured during read aloud, it affected the students' ability to express feelings and promote skills in their speaking. As a result, students became actively involved in the learning process. This condition confirms what Meyer, Stahl, and Wardop (1994) has contended that this strategy promote students' oral language experiences which eventually leads to the whole class discussion.

After listening to the story read aloud, the students were required to work in a group of five and perform a short play, which was very challenging and encouraging for them to perform in the very beginning of the study. Through practicing over and over, by and by the students became confident and were used to speaking in front of the class. This activity also assures the reason why students' vocal expression shows the most significant improvement among other speaking aspects in this study.

Moreover, it is assumed that the materials for reading aloud given to the students with certain contents and circumstances also contributed to the speaking improvement. This is possibly due to the fact that every word was not only pronounced properly but also arranged sense group by sense group based on the contents during their interactive reading aloud activities. The implementation of setting the tone and expression in such a way has helped students to focus 
on how the words were correctly pronounced with suitable stress, intonation and rhythm on certain parts of the story. This assumption also convinces the finding that the students' strength in speaking was on their pronunciation and fluency. Thus, the results of this present study have been in line with that of Kelly's (2004) to adult Chinese English language learners in China.

To sum up what have been discussed, the results of this present study have proven that interactive read aloud instructional strategy (IRAIS) could improve secondary students' English literacy achievement in general and certain aspects of its four sub-skills, listening, reading, writing, and speaking much better in particular.

\section{CONCLUSION}

The findings of this study prove that IRAIS is a powerful teaching strategy to improve students' English literacy. It does not only make a difference in English literacy skills but also its aspects. The most effective of IRAIS is that the students are actively involved and not only passively listening which eventually enables them to engage in thoughtful conversations and discussions, making predictions or inferences that explain character's motivations, connect events from different parts of the story, and learn new words. Therefore, reading aloud is a very good practice for promoting students' English proficiency by taking the following into account. First, time allocation for teaching the four English skills should be done equally to give more experience to the students to practice in the classroom, especially for speaking skill. Second, the readability of reading and listening materials should match with the students' level of reading. Therefore, prior to the experiment, it would be more effective, if future researchers do some assessments on the students' level of reading.

\section{REFERENCES}

Albright, L. K. (2002). Bringing the Ice Maiden to life: Engaging adolescents in learning through picture book read-alouds in content areas. Journal of Adolescent \& Adult Literacy, 45(5), 418-428.

Albright, L.K., \& Ariail, M. (2005). Tapping the potential of teacher read-alouds in middle schools. Journal of Adolescent and Adult Literacy, 48(7), 582-591.

Al-Mansour, N. S. \& Al-Shorman, R. A. (2011). The effect of teacher's storytelling aloud on the reading comprehension of Saudi elementary stage students. Journal of King Saud University - Languages and Translation, 23, 69-76.

Barrentine, S., J. (1996). Engaging with reading through interactive read-alouds. The Reading Teacher, 50(1), 36-43.

Biemiller, A., \& Boote, C. (2006). An effective method for building meaning vocabulary in primary grades. Journal of Educational Psychology, 98(1), 44-62.

Boundless Education. (2016). Effective teaching strategies. Retrieved from https://www.boundless.com/education/ textbooks/boundless-education-textbook/working- with-students-4/teaching-strategies-21/effectiveteaching-strategies-64-12994/.

Campbell, D. T., \& Stanley, J. C. (1963). Experimental and quasi-experimental design for research. Hope-well, NJ: Houghton Mifflin Company.

CIA. (2014). Definition of literacy and census bureau percentages for total population. Retrieved from http:// www.indexmundi.com/g/r.aspx? $=\mathrm{c}=\mathrm{id} \& \mathrm{v}=39$.

Crystal, D. (2003). English as a global language (2 ${ }^{\text {nd }}$ ed.). Cambridge, UK: Cambridge University Press.

Delacruz, S. (2013). Using interactive read-alouds to increase K-2 students' reading comprehension. Journal of Reading Education, 38(3), 21-27.

Diem, C. D., Vianty, M., \& Mirizon, S. (2017). Students' specific comprehension skills in English based on locations, grades, and gender. A paper presented at the $52^{\text {nd }} R E L C$ International Conference, Singapore, March 13-15.

Ediger, M. (2002). Reading aloud to aid pupil achievement. Retrieved from http://files.eric.ed.gov/fulltext/ ED468079.pdf.

EF-English Proficiency Index. (2015). EF English proficiency index 2015. Retrieved from http://www.ef.edu/epi/ regions/asia/indonesia/.

Fisher, B., \& Medvic, E.F. (2003). Perspective on shared reading: planning and practice. Portsmouth, NH: Heinemann.

Fountas, I. C., \& Pinnell, G.S. (2006). Teaching for comprehending and fluency: Thinking, talking, and writing about reading, $K-8$. Portsmouth, NH: Heinemann.

Graddol, D. (2006). English next: Why global English may mean the end of "English as a Foreign Language." London, UK: The British Council.

Hargrave, A. C., \& Sénéchal, M. (2000). A book reading intervention with preschool children who have limited vocabularies: The benefits of regular reading and dialogic reading. Early Childhood Research Quarterly, 15, 75-90.

Harmon, M. (2002). Teaching independent world learning strategies to struggling readers. Journal of Adolescent \& Adult Literacy, 45(7), 606-632.

Hoffman, J., L. (2011). Coconstructing meaning: Interactive literacy discussions in kindergarten read-alouds. The Reading Teacher, 65(3), 183-194.

IEA. (2012). PIRLS 2012 international results in reading. International Association for the Evaluation of Educational Achievement (IEA). Retrieved from http:// timsandpirls.bc.edu/pirls2011/downloads/P11_IR_Fullbook.Pdf.

Kelly, D. (2004). Reading aloud (out loud) in conversational English classes. TESL Journal, 10(7). Retrieved from http://iteslj.org/Techniques/Kelly ReadingAloud.html.

Koralek, D. (2003). Reading aloud with children of all ages. National Association for the Education of Young Children. Retrieved from https://www.naeyc.org/files/yc/ file/200303/ReadingAloud.pdf.

Lane, H. B., \& Wright, T. L. (2007). Maximizing the effectiveness of reading aloud. The Reading Teacher, 60, $668-75$ 
McGee, L. M., \& Schickedanz, J. A. (2007). Repeated interactive read-alouds in preschool and kindergarten. Reading Teacher, 60(8), 742-751.

Meyer, L. A., Stahl, S. A., \& Wardrop, J. L. (1994). Effects of reading storybooks aloud to children. Journal of Educational Research, 88, 69-85.

Ministry of Education and Culture. (2014). Materi pelatihan guru: Implementasi kurikulum 2013 tahun ajaran 2014/2015. Jakarta: Badan Pengembangan Sumber Daya Manusia dan Penjamin Mutu Pendidikan Kementrian Pendidikan dan Kebudayaan.

Nishida, H. (2007). Improving reading with the help of reading aloud. Cultural and Language Education Aichi University Laboratory Bulletin of language, 16, 117-131.

O'Flahavan, J. F. (2007). Interactive read aloud interactive reader. Retrieved from http://www.tolerance.org/sites/ tolerance.org.tdsi/files/assets/general/Interactive_Read Aloud.pdf?keyword=interactive-reader-reading.

Oshima, A., \& Hogue, A. (2007). Introduction to academic writing $\left(6^{\text {th }}\right.$ ed.). New York, NY: Pearson Education, Inc.
Oueini, H., Bahous, R., \& Nabhani, M. (2008). Impact of read-aloud in the classroom: A case study. The Reading Matrix, 8(1), 139-157.

Shed, M. K., \& Duke, N. K. (2008). The power of planning: Developing effective read-alouds. Beyond the Journal, 2(3), 1-6.

Stark, M. W. (1981). A group informal reading inventory: An instrument for the assessment of ESL students' reading performance. Retrieved from http://bit.ly/183SDUW.

Trerealese. (2011). The read-aloud handbook ( $7^{\text {th }}$ ed.). New York, NY: Penguin Group.

UNESCO Institute for Statistics. (2015). Indonesia literacy rate. Retrieved from http://www.uis.unesco.org/DataCentre/Pages/countryprofile.aspx? code=IDN\&sector $=1$.

United Nations. (2015). Transforming our world: The 2030 agenda for sustainable development. Retrieved from https://sustainabledevelopment.un.org/content/ documents/21252030\%20Agenda $\% 20$ for $\% 20$ Sustainable\%20Development $\% 20$ web.pdf. 